\title{
THE PROBLEM OF REPRESENTATION OF WOMEN IN NON-WESTERN FEMALE WRITER'S NOVELS
}

Zühal GÖKBEL 


\title{
(c) Copyright 2020
}

Printing, broadcasting and sales rights of this book are reserved to Akademisyen Publishing House Inc. All or parts of this book may not be reproduced, printed or distributed by any means mechanical, electronic, photocopying, magnetic paper and/or other methods without prior written permission of the publisher. Tables, figures and graphics cannot be used for commercial purposes without permission. This book is sold with banderol of Republic of Turkey Ministry of Culture.

\section{ISBN}

978-605-258-841-3

\section{Book Title}

The Problem of Representation of Women In Non-Western Female Writer's Novels

\author{
Author \\ Zühal GÖKBEL \\ Publishing Coordinator \\ Yasin Dilmen \\ Page and Cover Design
}

Typesetting and Cover Design by Akademisyen

Publisher Certificate Number

25465

Printing and Binding

Printing press Sonçağ Matbaacılık

Bisac Code

EDU000000

\section{GENERAL DISTRIBUTION}

Akademisyen Kitabevi A.Ş.

Halk Sokak 5 / A

Yenişehir / Ankara

Tel: o312 4311633

siparis@akademisyen.com

\section{www.akademisyen.com}




\section{CONTENTS}

\section{Chapter 1}

1.1 Western Originated Feminisms................................................ 9

a) French Feminism.................................................................. 19

b) Postmodern Feminism ....................................................... 24

1.2. As Alternatives to the Eurocentric Feminisms :

Transnational Feminism, Third World Feminism and Their Effects on Identity Formation ......................................................... 27

a) Third World Feminism ......................................................... 28

b) Transnational Feminism ..................................................... 31

1.3. Women and Representation of Gender in Western

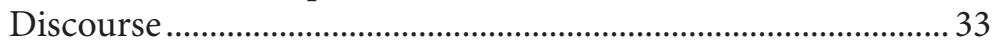

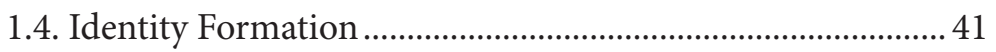

a) On a Foucauldian Terminology............................................ 45

b) Bhabha and Hybridity ............................................................... 49

\section{Chapter 2 White Teeth}

2.1. Representation on Women in

Zadie Smith's White Teeth................................................................. 53

2.2. Representation of Western Women in Western Societies

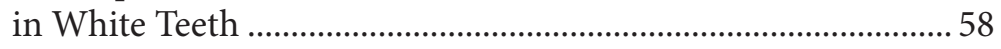

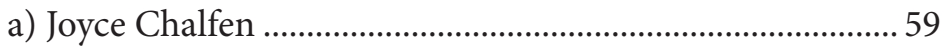

b) Poppy Burt - Jones................................................................. 64

2.3. Identity Formation and Representation of Non-Western Women in Western Societies in White Teeth ................................ 66

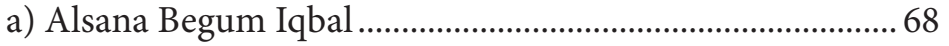

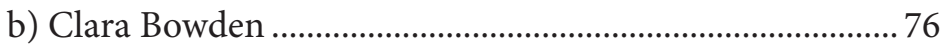

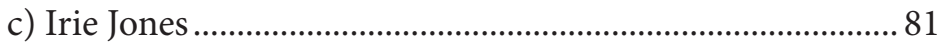

d) Neena Begum ...................................................................... 88

2.4. Dialectical Connection and Interaction among Western and Non-Western Women in White Teeth.....................91 


\section{Chapter 3 Honour}

3.1. Representation of Women in Honour

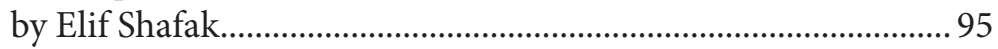

3.2. Representation of Non-Western

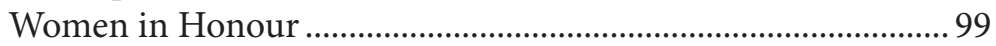

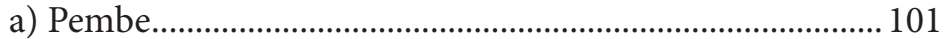

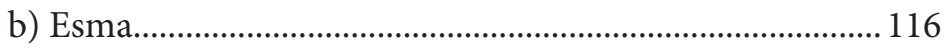

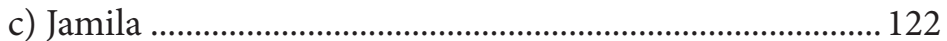

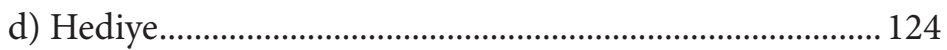

3.3. Representation of Non-Western Women in Honour ........ 126

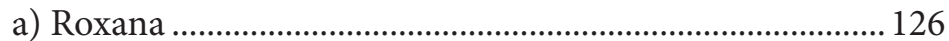

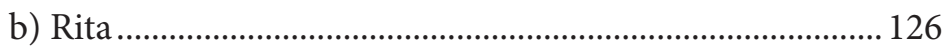

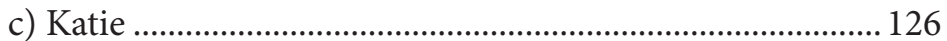

3.4. Dielectical Connection and Interaction among Western and Non-Western Women Characters......................... 127

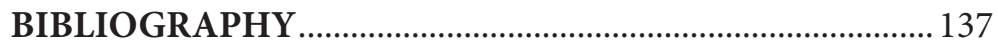




\section{BIBLIOGRAPHY}

Akçeşme, İfakat Banu. (2010). Comparative Discourse Analysis of Gender Constructions in the Novels of Robert Heinlein, Ursula Le Guin, Joanna Russ and Samuel Delany. Diss. Ankara; Metu.

Aksoy, Emel. (2007). "Zadie Smith'in White Teeth adlı Romanın Çevirisindeki “Öteki” Kavramına İmgebilimsel Yaklasım”, Muğla University, Instutiton of Social Sciences.

Allen, Amy. (1996). Foucault on Power: A theory for Feminists, chapter 11."Feminist Interpretations of Michel Foucault". Pennsylvania: The Pennsylvania University Press.

Arıkan, Seda. (2008) Individual and Social Conflict in Multicultural England: Zadie Smith's White Teeth and Monica Ali's Brick Lane, MA Thesis, FU, Elazı̆ .

Arıkan, Seda. (Ekim, 2011)."White Teeth ve İskender'de Yakınlaşmalar ve Kopuşlar”, Ayraç 24, pp. 3-14.

Arıkan, Seda. (February, 2013) "History and Root in Zadie Smith's White Teeth." International Journal of Social Science Volume 6 Issue 2, p. 1679-1696.

Aydoğdu, Yusuf. (2014). In the Novel of Alexander Fiction, Conflict elements and Characters, Atatürk University, Phd student at Faculty of Education.

Beukema, Taryn. (2008). Men Negotiating Identity in Zadie Smith's White Teeth, Postcolonial Text, McMaster University. Vol 4, No: 3

Bhabha, Homi. (1817) "Signs Taken for Wonders: Questions of Ambivalence and Authority under a Tree Outside Delhi”. London and New York: Routledge. Bhabha, Homi. (1994). The Location of Culture. London: Routledge.

Bhabha, Homi. (1935). Discourse in the Novel' in Michael Holquist (ed.), The Dialogic Imagination, trans. Caryl Emerson and Michael Holquist, Austin, Texas 1981, p. 360, cited from Homi K. Bhabha, 'Culture's In-Between', in Hall and du Gay, Questions of Cultural Identity, pp. 53-60.

Bartky, Sandra (1990) "Foucault, Femininity, and the Modernization of Patriarchal Power," in Femininity and Domination: Studies in the Phenomenology of Oppression New York: Routledge.

Beauvoir, Simone de (1949) Le deuxitme sexe. Paris: Gallimard. Trans Parshley, H.M. (1972) The Second Sex. Harmondsworth: Penguin.

Bowlby, Rachel. (Autumn, 1987) 'The Problem with No Name': Rereading Friedan's "The Feminine Mystique”, Feminist Review Palgrave Macmillan Journals, No: 27. pp.61-75. < http://www.jstor.org/stable/1394811>

Brenner, Johanna. (2000). 'Women and the Politics of Class' .Monthly Review, Portland State University in Portland, Oregon.

Bomarito, Jessica. Jeffrey W. Hunter. (2005). "Feminism in Literature" A Gale Critical Companion. Foreword by Amy Hudock, Ph. D University of South Carolina Volume 1: Antiquity-18th Century.

Butler, Judith. (1990). Gender Trouble. London \& New York: Routledge. 
Cavallora, Dani. (2003). French Feminist Theory, London \& New York: Continuum

Cavendish, Margaret. (1662) Playes and Orations of Divers Persons. <http:// www.lablit.com/article/411> ( accessed in 10.10.2017)

Celbis, Osman, Bora Ozdemir, Mucahit Oruc,nMustafa Dogan,bMucahit Egri,(2013) "Evaluation of Honour Killings in Turkey", Medicine Science, 2(2), p. 640-648 doi: 10.5455/medscience.2013.02.8081

Cixous, Helen. (Summer, 1976) The Laugh of Medusa. (Translated by Keith \& Paulo Cohen ) Journal of Women in Culture and Society. Signs, Vol. 1, No. 4, pp. 875-893. < http://www.jstor.org/stable/3173239>

Cornillon ,Susan Coppelman (1973) . Images of Women in Fiction Feminist Perspectives, Ohio: Bowling Green University Press.

Desai, Manisha. (Fall- Winter, 2007) "The Perils and Possibilities of Transnational Feminism". Women's Studies Quarterly. The Feminist Press Women's Studies Quarterly, Vol. 35, No. 3/4, Activisms pp.333-337. <http:// www.jstor.org/stable/27649726>

Danaher, Geoff, Tony Schirato and Jen Webb. (2000). Understanding Foucault. Australia: Sage Publication.

Davis, Kathy. Evans, Mary \& Lorber, Judith. (2006). Handbook of Gender and Women's Studies edt. Sage Publications, London. p. 32 -33.

De Beauvoir, Simone. (2011). The Second Sex. New York : Vintage Books.

De Lauretis, Terasa.(2007). Figures of Resistance, Urbana \& Chicago: University of Illinois Press. Print.

Dorli Dumescu, Patricia. (2017). "Colourful Teeth: A New Postcolonial Reality in Zadie Smith's Novel”, Journal Of Romanian Literary Studies. Issue no: 10, p.595-601.

Easthope, Antony. (1998). "Bhabha, hybridity and identity, Textual Practice" Hungarian Journal of English and American Studies (HJEAS), Centre for Arts, Humanities and Sciences (CAHS), Vol. 4, No. 1/2, 12:2, 341-348, $<$ http://www.jstor.org/stable/41273996>

Fava, Sylvia Fleis. (1963). “The Feminine Mystique by Betty Friedan, American "Sociological Association. Newyork.

Federica, Annette R. (2009). Gilbert \& Gubar's Madwoman in the Attic, Colombia and London: University of Missouri Press.

Ferguson, Ann. (2000). Resisting the veil of privilege: Building bridge identities as an ethico politics of global feminisms. Narayan and Harding: Decentering the center.

Ferree, Myra Marx. (2006). Global Feminism: Transnational Women's Activism, Organising, and Human Rights. New York University Press.

Freedman, Jane. (2001). Concepts in Social Sciences, Feminism. Buckingham, Philadelphia: Open University Press.

Foucault, Michel. (1972). The Archeology of Knowledge. London: Routledge.

Foucault, Michel. (1976). The History of Sexuality 
Foucault, Michel. (1978). The Use of Pleasure, Volume 2 of the History of Sexuality. New York: Vintage Books.

Foucault, Michel. (1980). Power/Knowledge: Selected Interviews and Other Writings 1972-1977. Ed. Colin Gordon. New York: Pantheon.

Friedan, Betty. (1963). The Feminine Mystique. New York: Dell.

Gambaudo, Sylvie A. (2007) . French Feminism vs Anglo-American Feminism, European Journal of Women's Studies, SAGE Publications (UK and US), 14 (2), pp.93-108. <10.1177/1350506807075816>. <hal-00571299>

Gardner, Barbara J. (2012) "Speaking Voices in Postcolonial Indian Novels from Orientalism to Outsourcing." Diss, Georgia State University.

Gayas, Gazala. (April,2016) "Suffering of Women characters in Elif Shafak's Novel Honour" International Multidisciplinary Research Journal ,Volume III Issue II: April 2016, p.12-17.

Gloria, Joseph. (1981). “The Incompatible Menage a Trois: Marxism, Feminism and Racism." In Lydia Sargent, ed., Women and Revolution. Boston: South End Press.

Gilbert, Sandra M. and Gubar, Susan. (1979). The Madwoman in the Attic: The Woman Writer and the Nineteenth-Century Literary Imagination. New Haven: Yale University Press.

Göle, Nilüfer. (1992). Modern Mahrem. Medeniyet ve Örtünme. İstanbul: Metis Yayınlar1.

Hadjetin, Slyvia. (2014). Multiculturalism and Magic Realism in Zadie Smith's Novel White Teeth: Between Fiction and Reality. Hamburg: Anchor Academic Publishing.

Hall, Stuart. (1989). "Ethnicity: Identity and Difference." Radical America Vol, 23:pp.9 - 20.

Hekman, Susan. (1995). Moral Voices/Moral Selves. Cambridge: Polity Press.

Hekman, Susan. (1996) "Feminist Interpretations of Michel Foucault". Bloomington: Pennsylvania State University Press.

Hekman, Susan. (2000). "Beyond Identity: Feminism, Identity and Identity Politics”. Feminist Theory. Vol 1. (3). pp.289-308. London: Sage Publications.

Hewitt, N. A. (2010). Introduction. In N. A. Hewitt (Ed.), No permanent waves: Recasting histories of U.S. feminism (pp. 1-14). New Brunswick, NJ: Rutgers University Press.

Hooks, bell. (2000). Feminism Is for Everybody: Passionate Politics South End Press Cambridge, MA, Library of Congress Cataloging-in-Publication Data

Hudhart, David. (2006). Routledge Critical Thinkers, Homi Bhabha, London and New York, Taylor and Francis Group.

Irigaray, Luce. (1993). Je, Tu, Vous, New York\& London: Routledge.

Jawich, Rihan. (2014). Hybridity and Multi-Culturalism in Zadie Smith's White Teeth, A term Paper submitted to Universitat Bonn.

Jones, Rachel Bailey. (2011). Postcolonial Representations of Women Critical Issues for Education. Dordrecht Heidelberg London New York: Springer. 
Karart1, Pinar. (2010). The Notion of Identity in Elif Shafak's Works, Published Master Thesis in English Language and Literature. İstanbul: Fatih University.

Katisko, Noora. (2011). Englishness Revisited: "The Construction of Hybrid National Identities in Zadie Smith's White Teeth, Pro Gradu Thesis, University of Tampere, School of Language, Translation and Literary Studies-English Philology.

Kirby, Vicky. (2006). Judith Butler, Live Theory. London: Continuum Press.

Korte (Freiburg), Barbara. "Blacks and Asians at War for Britain." Journal for the Study of British Cultures 14.1 (2007): 29-39. Print. (p.35)

Kourany Janet, James B. Sterba and Rosemarie Tong. (1992) Feminist Philosophies Problems, theories, and Applications. New Jersey: Printice Hall.

Kristeva, Julia. (1982). Power of Horror, New York: Colombia University Press

Leonard, Diana and Lisa Adkins. (1996). Sex in Questions: French Materialist Feminism Bristol: Taylor \& Francis Publisher

Levy, Andrea (2000). This is my England, The Guardian.

Mann, Susan Archer, Douglas J. Huffman. (Jan, 2005). “The Decentering of Second Wave Feminism and the Rise of the Third Wave" Science \& Society, Vol. 69, No. 1, Marxist-Feminist Thought Today, pp.56-91. Published by: Guilford Press

McLaren, Margaret A. (1997, Spring). Foucault and Subject of Feminism, Social Theory and Practice, Vol.23 No.1 Pp 109-128, Florida State University, USA.

McNay, Lois. (Fall, 1991). "The Foucauldian Body and the Exclusion of Experience", Hypatia p.125.

Meşe, İlknur. (Winter,2013). Ass. Prof. In Aksaray University. "Motherhood Creating its Killer: Based on Elif Shafak's Novel Alexander Questioning the Masculinity and Feminity Roles in Turkey." International Periodical For The Languages, Literature and History of Turkish or Turkic Volume 8/3, Ankara, p. 399-411.

Millet, Kate. (1970). Sexual Politics, New York: Doubleday \& Company, Inc.

Moi, Toril.(1985). Sexual/Textual Politics: Feminist Literary Theory. London \& New York: Routledge.

Moers, Ellen (1976). Literary Women: The Great Writers. New York: Doubleday. Reprinted (1977) London: The Women's Press.

Mohanty, Chandra Talpade, Ann Russo and Lourdes Torres. (1991). Third World Women and Politics of Feminism. Bloomington and Indianapolis: Indiana University Press.

Mohanty, Chandra Talpade. (1995). 'Under Western Eyes: Feminist scholarship and colonial Discourses', from The Post-Colonial Studies Reader. Bill Ashcroft, Gareth Griffiths, and Helen Tiffin. London and New York: Routledge.

Mohanty, Chandra Talpade. (2003). Feminism Without Borders.Decolonizing Theory, Practising Solidarity. Durhan \& London: Duke University Press. 
Moghadam, V. (2005). Globalizing women: Transnational feminist networks. Baltimore:

The Johns Hopkins University Press.

Moraga, Cherrie \& Gloria Anzaldua. (1983). eds. This Bridge Called My Back: Writings by Radical Women of Color. New York: Women of Color Press, 1983.

Moss, Laura. (2003). “The politics of everyday hybridity: Zadie Smith's White Teeth", Wasafiri, 18:39, 11-17, DOI: 10.1080/02690050308589837

Nichols, Sara. (Fall-Winter, 2001). "Biting off More Than you Can Chew: Review of Zadie Smith's "White Teeth", New Labor Forum, No.9, pp.62 66. <http://www.jstor.org/stable/40342313>

Offen, Karen. (1988). Defining Feminism: A Comparative Historical Approach. Vol 4. No.1, pp.119-157.The University of Chicago Press. < http://www.jstor.org/stable/3174664>

Oakland, John. (1998). British Civilization: An Introduction. London: Routledge, Print.

Okeyo, Achola Pala. (March-April 1981). "Reflection on Development Myths." Africa Report pp.7-10.

Oliver, Kelly. (2000). French Feminism Reader, Rowman \& Littlefield Publishers, Boston.

Phelan, Shane. (1990). "Foucault and Feminism", American Journal of Political Science, Vol. 34, No: 2, Pp. 421-440, Austin.

Phinney, Jean S. (2000). "Identity Formation across Cultures: The Interaction of Personal, Societal, and Historical Change" Human Development. California State University, Los Angeles, Calif. USA 43pp.27-31.< https:// www.karger.com/HDE>

Rampton, Martha. (May, 2017). “The Three Waves of Feminism”. The Magazine of Pacific University Vol. 41 No. 2. Pacific University., Fall 2008. Web. 3 Nov 2013 Steinman, Gloria. Interview by Stacey Tisdale.

Ratliff, Clancy. (2006). "Postmodern Feminism". The encyclopaedia of gender and information technology. (pp.1018-1022).Hershey: Idea Group Inc. <www.igi-global.com/chapter/postmodern-femenism/12865>

Russ, Joanna. (1983). How to Suppress Women's Writing. Austin: University of Texas Press.

Selden, Raman \& Peter Widdowson, Peter Brooker (2005). A Reader's Guide to Contemporary Literary Theory, Fifth Edition, London: Pearson \&Longman.

Sengupta, Jayita. (2006). Refractions of Desire Feminist Perspectives in the Novels of Toni Morrison, Michéle Roberts and Anita Desai. Delhi: Atlantic Publishers.

Shugart, Helene A., Catherine Egley Waggoner, and D. Lynn O’Brien Hallstein. ( June, 2001) "Mediating Third-Wave Feminism: Appropriation as Postmodern Media Practice." Critical Studies in Media Communication. Pp.194-210. <http://library.southalabama.edu>

Shafak, Elif. (2011). Honour, London: Penguin Books. 
Smith, Zadie. (2000). White Teeth. London: Penguin Books.

Showalter, Elaine (1977). A Literature of Their Own. British Women Novelists from Bronte to Lessing. Princeton, N.J.: Princeton University Press.

Steady, Filomina Chioma. (1985). "African Women at the End of the Decade." Africa Report (March/ April):4-8.

Snyder, R. Claire. (Autumn, 2008). What Is Third区Wave Feminism? A New Directions Essay. The University of Chicago Press Signs, Vol. 34, No. 1, pp. 175-196. < // www.jstor.org/stable/10.1086/588436>

Webster's II New College Dictionary, Third edition.

Weedon, Chris. (1987) Feminist practice and Poststructuralist theory Cambridge, Massachusett: Library Congress Cataloguing in Publication Data.

Wittig, Monique. (Winter,1981). “One is Not Born a Woman,” Feminist Issues, Vol. 1, No. 2.

Wittig, Monique. (1992) The Straight Mind and Other Essays Women's studies: Gay and lesbian studies. Boston: Beacon Press.

Woolf, Virginia. (1928) A Room of One's Own. London: Penguin Books.

Taylor, Charles. (1989). Sources of the self: The making of the modern identity. Cambridge: Harvard University Press.

Yağcl, Derya. (2013). "The Comparative Analysis of Motifs in White Teeth by Zadie Smith and Honour by Elif Shafak", Published Master Thesis, Isparta: Süleyman Demirel University.

Yang, L. (2003). Theorizing Asian America: On Asian American and postcolonial Asian diasporic women intellectuals. Journal of Asian American Studies. 5(2). 139-178.

Young, Robert J. C. (1995). Colonial Desire. Hybridity in Theory, Culture and Race. London and New York : Routledge

Weir, Allison. (2013). Identities and Freedom: Feminist Theory Between Power and Connection, New York: Oxford University Press.

Zileli, Irmak. (Ağustos, 2011). "Elif Şafak'la Söyleşi; En Zoru İskender Olmaktı.” Remzi Kitabevi Kitap Gazetesi. http://www.elifsafak.us/roportajlar. asp?islem=roportaj\&id=366 